\title{
Knowledge Level towards Cervical Cancer Among Students of Baabul Kamil Vocational High School
}

\author{
Windi Nurdiawan, ${ }^{1}$ Chrestella Odillia, ${ }^{2}$ Monica Risnadena Priyas, ${ }^{3}$ \\ Yosefa Resti Radinda, ${ }^{4}$ Nabila Alifia Ahmad, 5 Nur Agustina Ningsih, 5 \\ Qhonita Anif Febian, ${ }^{6}$ Andri Rezano ${ }^{7,8}$
}

${ }^{1}$ Department of Obstetrics and Gynecology, Faculty of Medicine, Universitas Padjadjaran/Dr. Hasan Sadikin General Hospital, Bandung, Indonesia, ${ }^{2}$ Faculty of Psychology, Universitas Padjadjaran, Sumedang, Indonesia, ${ }_{3}^{3}$ Faculty of Animal Husbandry, Universitas Padjadjaran, Sumedang, Indonesia, ${ }^{4}$ Faculty of Communication Science, Universitas Padjadjaran, Sumedang, Indonesia, ${ }^{5}$ Faculty of Nursing, Universitas Padjadjaran, Sumedang, Indonesia, ${ }^{6}$ Faculty of Geological Engineering, Universitas Padjadjaran, Sumedang, Indonesia, ${ }^{7}$ Department of Biomedical Sciences, Faculty of Medicine, Universitas Padjadjaran, Sumedang, Indonesia,

${ }^{8}$ Biomedical Sciences Master Program, Faculty of Medicine, Universitas Padjadjaran, Sumedang, Indonesia

\begin{abstract}
Cervical cancer is one of the most common causes of cancer-related death in women worldwide that is mostly preventable and treatable. Knowledge and awareness of cervical cancer screening programs allow the implementation of the prevention of cervical cancer. The community service program is aimed to increase the knowledge of adolescents about cervical cancer and its screening. It was a one-group pretest-posttest quasi-experimental study to measure the level of knowledge of 45 female students of Baabul Kamil Vocational High School, Jatinangor, Sumedang. The study was conducted in May-June 2018. The participants were asked 15 questions, which was an adaptation of previous questionnaires. The program was managed by a mini-lecture that focuses on cervical cancer risk factors and early detection. Furthermore, pretest and posttest were conducted to analyze the level of knowledge on the aforementioned aspects before and after the dissemination descriptively. The participants included in this study were mostly 16 years old (67\%). The average recognition of cervical cancer and its early detection was not high. The knowledge of cervical cancer among students of Baabul Kamil Vocational High School was found to be moderate. There is a significant improvement in knowledge level after dissemination. The efficacy of dissemination among female students at Baabul Kamil Vocational High School was apparent in knowledge change. However, good cancer awareness, especially cervical cancer, needs to be established and integrated through effective cancer educational programs in the school curriculum. Key intervention strategies are required to raise cancer awareness in support of taking precautions and early detection measures.
\end{abstract}

Keywords: Cancer awareness, cancer education, dissemination, early detection, screening program

\section{Tingkat Pengetahuan Siswi SMK Baabul Kamil tentang Kanker Serviks}

\begin{abstract}
Abstrak
Kanker serviks merupakan salah satu penyebab paling umum kematian terkait kanker pada wanita di seluruh dunia yang sebagian besar dapat dicegah dan diobati. Pengetahuan dan kesadaran tentang program deteksi dini kanker serviks merupakan upaya pencegahan kanker serviks. Program pengabdian pada masyakat ini bertujuan meningkatkan pengetahuan remaja tentang kanker serviks dan deteksi dininya. Penelitian ini merupakan penelitian one-group pretest-posttest quasi-experimental untuk mengukur tingkat pengetahuan 45 siswi SMK Baabul Kamil, Jatinangor, Sumedang. Penelitian ini dilaksanakan pada bulan Mei-Juni 2018. Responden diberikan 15 pertanyaan yang merupakan adaptasi dari kuesioner sebelumnya. Program ini dilakukan melalui penyuluhan tentang faktor risiko kanker serviks dan deteksi dininya. Selanjutnya, dilakukan pretest dan posttest untuk menganalisis tingkat pengetahuan aspek-aspek tersebut sebelum dan sesudah penyuluhan secara deskriptif. Responden yang terlibat dalam penelitian ini sebagian besar berusia 16 tahun (67\%). Identifikasi pengetahuan tentang kanker serviks dan deteksi dininya rerata tidak tinggi. Pengetahuan tentang kanker serviks di kalangan siswa SMK Baabul Kamil tergolong sedang. Terdapat peningkatan yang bermakna tingkat pengetahuan responden setelah diberikan penyuluhan Efektivitas sosialisasi di kalangan siswa perempuan di SMK Baabul Kamil terlihat dari perubahan pengetahuan. Namun, kesadaran kanker yang baik, khususnya deteksi dini kanker serviks perlu diatur dan diintegrasikan melalui program pendidikan kanker yang efektif dalam kurikulum sekolah. Langkah strategis diperlukan untuk meningkatkan kesadaran tentang kanker demi mendukung tindakan pencegahan dan deteksi dini.
\end{abstract}

Kata kunci: Deteksi dini, kesadaran kanker, pendidikan kanker, penyuluhan, program skrining

Received: 14 June 2020; Revised: 24 July 2020; Accepted: 17 November 2020; Published: 31 December 2020

Correspondence: Andri Rezano, dr., M.Kes., Ph.D. Department of Biomedical Sciences, Faculty of Medicine, Universitas Padjadjaran. Jln. Raya Bandung-Sumedang km 21, Jatinangor, Sumedang 45363, West Java, Indonesia. E-mail: andri.rezano@unpad.ac.id 


\section{Introduction}

Cancer is a global public health issue. The number of cases and deaths due to the disease increase every year. ${ }^{1}$ WHO predicted that there would be around $60-81 \%$ increase in new cancer cases every year in the next two decades. Therefore, more severe cancer treatment measures are needed in low- and middle-income countries, which currently have the lowest survival rates. ${ }^{2}$ According to global cancer statistics 2018, GLOBOCAN cervical cancer ranks second as cancer with the highest incidence in Indonesia. ${ }^{3}$ The high prevalence of cancer and the late handling of cases in Indonesia require preventive actions and early detection efforts to ensure proper treatment and extend life expectancy. ${ }^{4}$

Universal human papillomavirus (HPV) vaccination remains out of reach for many countries. Therefore, an important strategy for integrating primary (HPV contact prevention and HPV vaccination) and secondary (screening) cervical cancer prevention must be taken as soon as possible. Cervical cancer burden has been dramatically reduced in countries that have implemented wide-scale screening program through cytological screening. ${ }^{5-7}$

According to WHO's national guideline, adolescents (aged 10-19 years old) are a key component of a multidisciplinary cervical cancer prevention and control program. The WHO national program consisted of community education, social mobility, immunization, reproductive health, adolescent health, and sexually-transmitted infections. ${ }^{8}$ One of the problems that are caused by the lack of knowledge in reproductive health is cervical cancer. Every hour, an Indonesian woman passes away due to cervical cancer in the past three decades. ${ }^{9}$

Cervical cancer is a malignant tumor that grows at the boundary between the epithelium lining the ectocervix (portio) and the endocervical cervical canal called the squamocolumnar junction. ${ }^{10}$ Sexual activity and HPV infection are the main causes of cervical cancer. ${ }^{11}$ Infection occurs through direct contact from small lesions on the skin or mucosa during sexual intercourse or when a baby goes through the infected birth canal. Multiple sexual partners, family history of cervical cancer, and the immune system are the main risk factors of cancer development. ${ }^{12}$ Mucosal HPV is divided into low-risk HPV, and high-risk HPV, ${ }^{13}$ which low-risk HPVs are known for not causing cancer, namely HPV type 6, 11,
$40,42,43,44,54,61,70,72$, and 81, and highrisk HPVs have a high tendency to cause cancer, namely HPV type $16,18,31,33,35,39,45,51,52$, $56,58,59,68,73$, and $82 .{ }^{13,14}$ A study in Bandung found that the most common genotypes in Dr. Hasan Sadikin Hospital are HPV type 16, 18, 45 dan $52 .{ }^{15}$

The Government of Indonesia has implemented visual inspections using acetic acid (VIA) screening in the public health center (puskesmas) since 2015 as it is affordable, available, and accessible. ${ }^{15,16}$ Eighty percent of women aged 30-50 years were targeted for free VIA screening in puskesmas. ${ }^{17,18}$ The program reached 575,503 people, with 25,805 women showed positive VIA results until 2012 and 666 women suspected of cervical cancer. ${ }^{17}$ Previous reports on rural community perception regarding cervical cancer and screening uptake for VIA has not been achieved due to the lack of knowledge of women about cervical cancer and its early detection methods. ${ }^{19,20}$ In parallel, people with better knowledge of reproductive health will be more likely to be in support of taking precautions and early detection measures. Through dissemination, access to information related to reproductive health is seen as influential in determining the risk levels of behaviors that might cause cervical cancer in women. ${ }^{20}$

At present, little is known about cervical cancer-related knowledge of cervical cancer, risk factors, symptoms, and prevention among adolescents. However, this group is at a vulnerable risk of acquiring HPV infection. Based on the problems that have been described, this study aimed to identify the level of knowledge on early detection of cervical cancer, especially among students of Baabul Kamil Vocational High School (SMK) in Jatinangor, Sumedang, West Java. This study seeks to increase students' knowledge about the early detection of cervical cancer through dissemination to adolescents. Expanding access and awareness of avoidable cervical cancer risk factors among adolescents are associated with certain preventive health-related behaviors, which can be a basis for healthy adulthood. ${ }^{21}$

\section{Methods}

This study used a quasi-experimental one-group pretest-posttest research design on all students of Baabul Kamil SMK, Jatinangor, Sumedang. A questionnaire survey was developed to achieve the aim of the study. The questionnaire's items were 
adapted from a validated questionnaire from a similar study conducted previously by Liu et al.,21 which divides knowledge into three domains: knowledge of symptoms, risk factors, and early detection of cervical cancer. The questionnaire was delivered in Bahasa and was revalidated in a similar population to the study sample. The final validated questionnaire was used in this study.

The method used in the study was dissemination regarding the early detection of cervical cancer by measuring the results of the questionnaires distributed before and after dissemination. The measurement of knowledge used the Guttman scale, in which the number of correct and wrong answers to the item was identified..$^{22}$ Each correct response of the study was scored one mark, and the wrong answer was scored with a zero. The total score obtained by each study subject was converted to a percentage. Interpretation of the level of knowledge is arbitrarily measured through the cumulative number of correct scores to the total score. A higher cumulative score signifies a higher level of knowledge, with the interpretation of the percentage scale of $>75 \%, 50-75 \%,<50 \%$ as, respectively, good, sufficient, and bad.

The data was analyzed using SPSS version 20 (SPSS Inc., U.S.A.). The $t$ test was used to distinguish the proportions of the pretest and posttest. The value of $\mathrm{p}<0.05$ was considered significant. The research is conducted in Baabul Kamil SMK, Jatinangor, about $30 \mathrm{~km}$ from Bandung city center, in May-June 2018. There was no dissemination or research about the knowledge level on the early detection of cervical cancer in the research location.

This study has received ethics approval from the Health Research Ethics Committee of Universitas Padjadjaran Bandung number 567/UN6.KEP/EC/2018 and respondents had received informed consent regarding their participation in this study.

\section{Results}

Forty-six samples were obtained in this study. However, one sample was not included in the research data because the respondent was not present at the posttest, so the total sample used for data analysis was 45. Data on the respondents' characteristics were obtained through the information filled by respondents in the questionnaire. The data that was taken for this research include respondents' age, marital status,
Table 1 Respondent Characteristics

\begin{tabular}{lrr}
\hline Characteristics & $\mathbf{n = 4 5}$ & $\mathbf{\%}$ \\
\hline Age (years) & & \\
14 & 7 & 2 \\
15 & 30 & 67 \\
16 & 7 & 16 \\
17 & & \\
Marital status & 45 & 100 \\
Single & 0 & 0 \\
Married & & \\
Education & 14 & 31 \\
Nursing students & 6 & 13 \\
Multimedia students & 18 & 40 \\
Administration office students & 7 & 16 \\
Female student - unknown & 70 \\
\hline
\end{tabular}

education, and previous information exposure, which can be seen in Table 1 . The majority of the respondents were 16 years old (67\%), single, and were vocational school students majoring in an administrative office.

Data on respondents' previous information sources can be seen in Table 2. Almost all respondents were informed through television, while the rest of the respondents were informed by health workers, seminars, and more than one information source and were never exposed to information about cervical cancer before.

The knowledge about cervical cancer assessment and its early detection before and after the dissemination can be seen in Table 3 .

Table 3 showed that meaningful changes were recorded regarding recognition of precancerous clinical symptoms, risk factors, and cervical cancer screening objectives, with respectively 0.025; 0.035; and 0.014. Meanwhile, a significant increase in knowledge was not recorded ( $p>0.05)$

\section{Table 2 Previous Information Source}

\begin{tabular}{lcc}
\hline Characteristics & $\mathbf{n}=\mathbf{4 5}$ & $\mathbf{\%}$ \\
\hline No previous exposure & 4 & 9 \\
Radio & O & O \\
Television & 29 & 64 \\
Newspaper/magazine & 3 & 7 \\
Seminar & 2 & 4 \\
Health workers & 2 & 4 \\
More than one source & 2 & 4 \\
Other sources & 0 & 0 \\
Blank (no answer) & 3 & 7 \\
\hline
\end{tabular}


Table 3 Knowledge about Cervical Cancer and Its Early Detection

\begin{tabular}{|c|c|c|c|}
\hline Questions about Cervical Cancer & $\begin{array}{c}\text { Pretest Score } \\
(0-1)\end{array}$ & $\begin{array}{c}\text { Posttest Score } \\
(0-1)\end{array}$ & p Value ${ }^{\diamond}$ \\
\hline Not a hereditary disease (genetic) & 0.57 & 0.62 & 1.000 \\
\hline Has a long precancerous period & 0.89 & 0.89 & 0.411 \\
\hline $\begin{array}{l}\text { Cervical cancer can be treated if it was detected } \\
\text { early }\end{array}$ & 0.68 & 0.62 & 0.225 \\
\hline $\begin{array}{l}\text { Cervical cancer patients who are receiving } \\
\text { treatment can have a life expectancy rate of }>10 \\
\text { years }\end{array}$ & 0.55 & 0.51 & 0.405 \\
\hline $\begin{array}{l}\text { Post-menopause women are still at risk of cervical } \\
\text { cancer }\end{array}$ & 0.26 & 0.15 & 0.223 \\
\hline HPV infection is the main cause of cervical cancer & 0.83 & 0.96 & 0.096 \\
\hline $\begin{array}{l}\text { Women with HPV (+) may not turn into cervical } \\
\text { cancer }\end{array}$ & 0.49 & 0.53 & 1.000 \\
\hline $\begin{array}{l}\text { Hygiene of the sexual organ prevents cervical } \\
\text { cancer }\end{array}$ & 0.81 & 0.94 & 0.102 \\
\hline $\begin{array}{l}\text { The precancerous lesion is asymptomatic in } \\
\text { cervical cancer }\end{array}$ & 0.34 & 0.57 & $0.025^{*}$ \\
\hline $\begin{array}{l}\text { Post-intercourse bleeding is one of the symptoms } \\
\text { of cervical cancer }\end{array}$ & 0.47 & 0.66 & 0.102 \\
\hline $\begin{array}{l}\text { Early sexual activity is one of the risk factors for } \\
\text { cervical cancer }\end{array}$ & 0.77 & 0.96 & $0.035^{*}$ \\
\hline $\begin{array}{l}\text { A precancerous lesion can be detected earlier in } \\
\text { cervical cancer }\end{array}$ & 0.74 & 0.87 & 0.096 \\
\hline $\begin{array}{l}\text { Women aged } 21-65 \text { years old must be tested for } \\
\text { the detection of cervical cancer every three years }\end{array}$ & 0.28 & 0.21 & 0.405 \\
\hline $\begin{array}{l}\text { Pap smear is one of the main methods of detecting } \\
\text { cervical cancer }\end{array}$ & 0.81 & 0.94 & 0.096 \\
\hline $\begin{array}{l}\text { The purpose of early identification of cervical } \\
\text { cancer is to find a precancerous lesion }\end{array}$ & 0.81 & 0.98 & $0.014^{*}$ \\
\hline Overall average $(n=45)$ & 0.65 & 0.69 & \\
\hline
\end{tabular}

Note: ${ }^{\circ}$ Wilcoxon test; ${ }^{*} \mathrm{p}<0.05$

on questions about whether cervical cancer is a hereditary disease (genetics) or not. It also not recorded for the precancerous period, early detection of cervical cancer, life-expectancy rate after active treatment, relations between menopause and cervical cancer, HPV infection, diagnosis, hygiene of sexual organ and cervical cancer, clinical symptoms in stadiums (postintercourse bleeding), screening, screening frequency, and screening method. The data shows the average recognition of cervical cancer and its early detection was not high (before and after dissemination, $65 \%$, and $69 \%$ respectively).

The Shapiro-Wilk method was used to test the normality of data, and both had a normal distribution $(p>0.05)$. Data on the level of knowledge of respondents before and after the dissemination is stated in Table 4.

Table 4 Analysis of the Knowledge Level Before and After Dissemination

\begin{tabular}{lccccc}
\hline Type of Test & n & Average+s.b & $\begin{array}{c}\text { Average } \\
\text { Difference+s.b }\end{array}$ & 95\% CI $^{\mathbf{p ~ V a l u e ~}^{\diamond}}$ \\
\hline Pretest score (before dissemination) & 45 & $77.04 \pm 9.163$ & $3.778 \pm 6.512$ & $1.821-5.734$ & $<0.0001$ \\
Posttest score (after dissemination) & 45 & $80.82 \pm 7.389$ & & & \\
\hline
\end{tabular}

Note: ${ }^{\circ}$ paired t test; $\mathrm{CI}=$ confidence interval 
Table 4 indicates that female students of Baabul Kamil SMK had adequate knowledge about cervical cancer. $\mathrm{T}$ test results show that $\mathrm{p}<0.0001$, hence it can be concluded that there was a significant increase in knowledge after cervical cancer dissemination.

\section{Discussion}

Cervical cancer can be prevented and treated if the changes in cervical cells or tissue are identified early..$^{4-7}$ One of the risk factors of cervical cancer is early sexual activity, and a history of promiscuity can increase exposure to sexually-transmitted infections, especially HPV as the cause of cervical cancer development. ${ }^{11-14}$ Coverage level of HPV vaccination as the primary prevention of cervical cancer remains out of reach in a few low-income and middle-income countries. ${ }^{6}$ Screening of cervical cancer (secondary prevention) by identifying precancerous lesions has dramatically reduced cervical cancer burden., ${ }^{6,23}$ This study examined cervical cancer-related knowledge of risk factors, symptoms, and screening among female high school students in Jatinangor, Sumedang, Indonesia. A previous study had been conducted to examine knowledge of HPV vaccination and screening for cervical cancer among women in Yogyakarta province. ${ }^{23}$ This study focused on the adolescent group, girls aged 14-17 years.

The level of knowledge on cancer signs and symptoms, early detection of cervical cancer positively correlates with a change in behavior on cervical cancer prevention..$^{20,24-27}$ Poor knowledge of cancer combined with negative beliefs and attitude has been considered the main reason for the late presentation and diagnosis of cancer, particularly if the symptoms are atypical..$^{29,30}$

Our present study showed that most respondents identified a range of cervical cancer information, such as television, newspaper/ magazine, seminar, and health workers, while only $15.6 \%$ had not previously heard of cervical cancer.

This study identified that knowledge about cervical cancer and its early detection was not relatively high. Our finding regarding the knowledge level was consistent with the previous study in Indonesia. ${ }^{23,24}$ The knowledge of some aspects was very low, such as postmenopause women still have the risk of getting cervical cancer; cervical cancer is asymptomatic in the precancerous lesion. Women should be screened for cervical cancer at least every three years. On the other hand, most of the respondents knew that cervical cancer has a long precancerous lesion period, and HPV infection is the main cause of cervical cancer. Maintaining sexual hygiene can prevent cervical cancer; cervical smear (pap smear) is a major cervical cancer screening method to discover precancerous lesions. Knowledge insufficiency regarding cervical cancer and its screening also occurred in other settings. For instance, inadequate knowledge was found among Tanzanian women at a low level, ${ }^{25}$ and Nigerian women, ${ }^{26}$ and female teachers in North-Western Nigeria. ${ }^{27}$ Hence, it can be said that literacy regarding cervical cancer disease and prevention was globally low and different in which aspects they were lack. The observed difference here could be attributed to the composition of the study population. It may be related to their perception of the test. Although the impact on younger people is lesser than adults regarding avoidable cancer risk factors due to lower rates of exposure over time, awareness of these factors among teenager are associated with certain protective health-related behaviors. ${ }^{28}$ A study by Due et al. ${ }^{29}$ reported that adult health results from exposures and processes over the entire life course. Therefore, raising cancer awareness among teenagers should lead to health behaviors in adulthood. ${ }^{29-31}$

This research is significant as the dissemination of cervical cancer and its early detection to students in Baabul Kamil SMK in Jatinangor would increase their knowledge and intergenerational transmission on the issue and help them make the right decision in the future.

In this study, there are limitations related to post-dissemination follow-up due to the researchers' limited time and respondents' activities in school. We would have gained a clear picture of respondents' level of knowledge if we recollected the data three months after the dissemination. Future studies should enlarge the number of respondents and use a random sampling technique for better study results representing Indonesia's situation and to provide generalizable results.

Currently, access to information has become a public necessity. Information can be obtained from the internet, social media, print media, and outdoor media. The reproductive health dissemination program for adolescents around Jatinangor subdistrict needs to be improved so that adolescents' understanding of health 
problems, especially prevention and early detection of cervical cancer, can also be improved. The incorporation of materials on adolescent reproductive health through social media, posters, billboards, and high school curricula could positively impact students' knowledge and change their behavior towards reproductive health. Hence, it will provide population-based health awareness education globally.

\section{Conclusions}

Having good knowledge and perception regarding cervical cancer among adolescent allow behavior change in cervical cancer prevention. Most of the vital adult health behaviors are initiated or significantly influenced by adolescence. It is necessary to promote school-based cancer education programs to support prevention and early detection measures.

\section{Conflict of Interest}

The authors declare that there was no conflict of interest.

\section{Acknowledgments}

This study was supported by the Internal Grant of Universitas Padjadjaran 2018, through Fundamental Research Grants Scheme integrated to Community Service Program by Lecturer and Students (No. 2477/UN6.C/PM/2018). The authors would like to thank all people involved in this study, especially the Head of Baabul Kamil Vocational High School and teachers for the time and facilities during the community service program.

\section{References}

1. Siegel R, Naishadham D, Jemal A. Cancer statistics, 2012. CA Cancer J Clin. 2012;62(1):10-29.

2. International Agency for Research on Cancer. WHO outlines steps to save 7 million lives from cancer [Internet]. Lyon: International Agency for Research on Cancer; 2020 February 4 [cited 2020 May 27]. Available from: https://www.iarc.fr/wp-content/ uploads/2020/02/pr279_E.pdf.

3. International Agency for Research on Cancer. GLOBOCAN 2018: estimated cancer incidence, mortality, and prevalence in Indonesia in 2018 [Internet]. Lyon: International Agency for Research on Cancer; 2018 [cited 2020 May 27]. Available from: https://gco.iarc.fr/today/data/factsheets/ populations/360-indonesia-fact-sheets.pdf.

4. Pusat Data dan Informasi, Kementerian Kesehatan Republik Indonesia. Situasi penyakit kanker. Jakarta: Pusat Data dan Informasi, Kementerian Kesehatan Republik Indonesia; 2015 [cited 2018 August 11]. Available from: https://pusdatin.kemkes. go.id/resources/download/pusdatin/ infodatin/infodatin-kanker.pdf.

5. Brotherton JML, Gertig DM. Primary prophylactic human papillomavirus vaccination programs: future perspective on global impact. Expert Rev Anti Infect Ther. 2011;9(8):627-39.

6. Poljak M. Prophylactic human papillomavirus vaccination and primary prevention of cervical cancer: issues and challenges. Clin Microbiol Infect. 2012;18(Suppl 5):64-9.

7. $\mathrm{Hu} \mathrm{Z}, \mathrm{Ma} \mathrm{D}$. The precision prevention and therapy of HPV-related cervical cancer: new concepts and clinical implications. Cancer Med. 2018;7(10):5217-36.

8. World Health Organization. Comprehensive cervical cancer control: a guide to essential practice. $2^{\text {nd }}$ edition. Geneva: WHO Press; 2014.

9. Romadhoni, Yazid N, Aviyanti D. Penyerapan pengetahuan tentang kanker serviks sebelum dan sesudah penyuluhan. J Kedokt Muhammadiyah. 2012;1(1):38-42.

10. Barrios De Tomasi J, Opata MM, Mowa CN. Immunity in the cervix: interphase between immune and cervical epithelial cells. J Immunol Res. 2019;2019:7693183.

11. Bosch FX, Broker TR, Forman D, Moscicki AB, Gillison ML, Doorbar J, et al. Comprehensive control of human papillomavirus infections and related diseases. Vaccine. 2013;31(Suppl 8):I1-31.

12. Murray PR, Rosenthal KS, Pfaller MA. Medical microbiology. $8^{\text {th }}$ edition. Philadelphia: Elsevier; 2015.

13. Winer RL, Hughes JP, Feng Q, Xi LF, Cherne S, O'Reily S, et al. Early natural history of incident, type-specific human papillomavirus infections in newly sexually active young women. Cancer Epidemiol Biomarkers Prev. 2011;20(4):699-707.

14. Miller DL, Puricelli MD, Stack MS. Virology and molecular pathogenesis of 
human papillomavirus (HPV)-associated oropharyngeal squamous cell carcinoma. Biochem J. 2012;443(2):339-53.

15. Tobing MDL, Sahiratmadja E, Dinda M, Hernowo BS, Susanto H. Human papillomavirus genotypes profile in cervical cancer patients at Dr. Hasan Sadikin General Hospital, Bandung, Indonesia. Asian Pac J Cancer Prev. 2014;15(14):5781-5.

16. Biro Komunikasi dan Pelayanan Publik Kementerian Kesehatan Republik Indonesia. Pemerintah targetkan 80\% perempuan dapat deteksi dini kanker payudara dan kanker serviks [Internet]. Jakarta: Biro Komunikasi dan Pelayanan Publik Kementerian Kesehatan Republik Indonesia; 2013 October 3 [cited 2020 Mei 27]. Available from: https://sehatnegeriku.kemkes.go.id/baca/ rilis-media/20131003/048785/pemerintahtargetkan-8o-perempuan-dapat-deteksidini-kanker-payudara-dan-kanker-serviks.

17. Setiawan D, Andrijono A, Hadinegoro SR, Meyta H, Sitohang RV, Tandy G, et al. Cervical cancer prevention in Indonesia: an updated clinical impact, cost-effectiveness and budget impact analysis. PLoS One. 2020;15(3):eo230359.

18. Mirayashi D, Raharjo W, Wicaksono A. Hubungan antara tingkat pengetahuan tentang kanker serviks dan keikutsertaan melakukan pemeriksaan inspeksi visual asetat di Puskesmas Alianyang Pontianak. J Mahasiswa PSPD FK Universitas Tanjungpura. 2014;1(1):7830.

19. Spagnoletti BRM, Bennett LR, Wahdi AE, Wilopo SA, Keenan CA. A qualitative study of parental knowledge and perceptions of human papillomavirus and cervical cancer prevention in rural Central Java, Indonesia: understanding community readiness for prevention interventions. Asian Pac J Cancer Prev. 2019;20(8):2429-34.

20. Al-Azri M, Al-Saadi WI, Al-Harrasi A, Murthi Panchatcharam S. Knowledge of cancer risk factors, symptoms, and barriers to seeking medical help among Omani adolescents. Asian Pac J Cancer Prev. 2019;20(12):365566.

21. Liu T, Li S, Ratcliffe J, Chen G. Assessing knowledge and attitudes towards cervical cancer screening among rural women in eastern China. Int $\mathrm{J}$ Environ Res Public Health. 2017;14(9):967.

22. CamizS.The Guttman effect: its interpretation and a new redressing method. Data Anal Bull. 2005;5:7-34.

23. Endarti D, Satibi S, Kristina SA, Farida MA, Rahmawanti Y, Andriani T. Knowledge, perception, and acceptance of HPV vaccination and screening for cervical cancer among women in Yogyakarta province, Indonesia. Asian Pac $\mathrm{J}$ Cancer Prev. 2018;19(4):1105-11.

24. Safaeian M, Solomon D, Castle PE. Cervical cancer prevention--cervical screening: science in evolution. Obstet Gynecol Clin North Am. 2007;34(4):739-60.

25. Lyimo FS, Beran TN. Demographic, knowledge, attitudinal, and accessibility factors associated with uptake of cervical cancer screening among women in a rural district of Tanzania: three public policy implications. BMC Public Health. 2012;12:22.

26. Wright KO, Faseru B, Kuyinu YA, Faduyile FA. Awareness and uptake of the Pap smear among market women in Lagos, Nigeria. J Public Health Afr. 2011;2(1):e14.

27. Adamu AN, Abiola AO, Ibrahim M. The effect of health education on the knowledge, attitude, and uptake of free Pap smear among female teachers in Birnin-Kebbi, North-Western Nigeria. Niger J Clin Pract. 2012;15(3):326-32.

28. Kyle RG, Forbat L, Hubbard G. Cancer awareness among adolescents in Britain: a cross-sectional study. BMC Public Health. 2012;12:580.

29. Due P, Krølner R, Rasmussen M, Andersen A, Trab Damsgaard M, Graham H, et al. Pathways and mechanisms in adolescence contribute to adult health inequalities. Scand J Public Health. 2011;39(Suppl 6):62-78.

30. Sherpa AT, Karki BS, Soundby J, Nygard M, Fransceschii S, Clifford G. Population based study of cervical cancer screening in Bharatpur, Nepal. J Manmohan Mem Inst Health Sci. 2015;1(4):3-8.

31. Zhang D, Li X, Xue J. Education inequality between rural and urban areas of the People's Republic of China, migrants' children education, some implications. Asian Dev Rev. 2015;32(1):196-224. 